medRxiv preprint doi: https://doi.org/10.1101/2020.05.17.20104547; this version posted May 22,2020 . The copyright holder for this preprint (which was not certified by peer review) is the author/funder, who has granted medRxiv a license to display the preprint in perpetuity. All rights reserved. No reuse allowed without permission.

\title{
Meteorological Conditions and Covid-19 in Large U.S. Cities
}

Hisato Takagi, M.D., Ph.D., Toshiki Kuno, M.D., Ph.D., Yujiro Yokoyama, M.D., Hiroki Ueyama, M.D., Takuya Matsushiro, M.D. Yosuke Hari, M.D., Tomo Ando, M.D.

Shizuoka Medical Center, Shizuoka, Kitasato University, School of Medicine, Sagamihara, Japan (HT, TM, YH), Mount Sinai Beth Israel Medical Center, New York, NY, USA (TK, HU), Easton Hospital, Easton, PA, USA (YY), New York Presbyterian Hospital/Columbia University Medical Center, New York, NY, USA (TA) 


\begin{abstract}
To determine whether prevalence of Coronavirus disease 2019 (Covid-19) is modulated by meteorological conditions, we herein conducted meta-regression of data in large U.S. cities. We selected 33 large U.S. cities with a population of $>500,000$. The integrated numbers of confirmed Covid-19 cases in the country to which the city belongs on 14 May 2020, the estimated population in 2019 in the country, and monthly meteorological conditions at the city for 4 months (from January to April 2020) were obtained. Meteorological conditions consisted of mean temperature (F), total precipitation (inch), mean wind speed (MPH), mean sky cover, and mean relative humidity (\%). Monthly data for 4 months were averaged or integrated. The Covid-19 prevalence was defined as the integrated number of Covid-19 cases divided by the population. Random-effects meta-regression was performed by means of OpenMetaAnalyst. In a meta-regression graph, Covid-19 prevalence (plotted as the logarithm transformed prevalence on the yaxis) was depicted as a function of a given factor (plotted as a meteorological datum on the x-axis). A slope of the meta-regression line was significantly negative (coefficient, $-0.069 ; \mathrm{P}<0.001)$ for the mean temperature and significantly positive for the mean wind speed (coefficient, 0.174; $\mathrm{P}=0.027$ ) and the sky cover (coefficient, 2.220; $\mathrm{P}=0.023$ ). In conclusion, lower temperature and higher wind speed/sky cover may be associated with higher Covid-19 prevalence, which should be confirmed by further epidemiological researches adjusting for various risk and protective factors (in addition to meteorological conditions) of Covid-19.
\end{abstract}




\section{Text}

\section{Introduction}

Higher temperature and ultraviolet (UV) index in Northern Europe have been reported as the most important meteorological protective factors for the transmission of influenza virus. ${ }^{1}$ On the other hand, a recent study in China suggests that higher temperature and UV radiation may not be associated with a decrease in the epidemics of Coronavirus disease 2019 (Covid-19). ${ }^{2} \quad$ To determine whether prevalence of COVID-19 is modulated by meteorological conditions, we herein conducted meta-regression of data in large U.S. cities.

\section{Methods}

We selected 33 large U.S. cities with a population of $>500,000$ in 2010 from the U.S. Census Bureau (http://www.census.gov). The integrated numbers of confirmed Covid19 cases in the country to which the city belongs on 14 May 2020 from the Johns Hopkins Coronavirus Resource Center (https://coronavirus.jhu.edu), the estimated population in 2019 in the country from the U.S. Census Bureau, and monthly meteorological conditions at the city for 4 months (from January to April 2020) from the National Weather Service (https://www.weather.gov) were obtained (Table 1). Meteorological conditions consisted of mean temperature (F), total precipitation (inch), mean wind speed (MPH), mean sky cover, and mean relative humidity (\%). Monthly data for 4 months were averaged or integrated. The Covid-19 prevalence was defined as the integrated number of Covid-19 cases divided by the population. Random-effects meta-regression was performed by means of OpenMetaAnalyst 
medRxiv preprint doi: https://doi.org/10.1101/2020.05.17.20104547; this version posted May 22, 2020. The copyright holder for this preprint (which was not certified by peer review) is the author/funder, who has granted medRxiv a license to display the preprint in perpetuity.

All rights reserved. No reuse allowed without permission.

\section{4}

(http://www.cebm.brown.edu/openmeta/index.html). In a meta-regression graph, Covid-19 prevalence (plotted as the logarithm transformed prevalence on the y-axis) was depicted as a function of a given factor (plotted as the meteorological data on the x-axis).

\section{Results}

Results of the meta-regression were summarized in Table 2. A slope of the metaregression line was significantly negative (coefficient, $-0.069 ; \mathrm{P}<0.001$; Figure 1, upper panel) for the mean temperature (indicating that Covid-19 prevalence decreased significantly as the mean temperature increased) and significantly positive for the mean wind speed (coefficient, 0.174; $\mathrm{P}=0.027$; Figure 1, middle panel) and the sky cover (coefficient, 2.220; $\mathrm{P}=0.023$; Figure 1, lower panel) (indicating that Covid-19 prevalence increased significantly as the mean wind speed and the sky cover increased).

\section{Discussion and Conclusion}

The present meta-regression suggests that temperature may be negatively and wind speed/sky cover may be positively associated with COVID-19 prevalence. Higher sky cover is probably related to lower UV radiation. Our recent preliminary study of Japanese prefectural data suggests that temperature and UV index may be negatively associated with COVID-19 prevalence, ${ }^{3}$ which could strengthen the present findings. Despite the association of lower temperature and UV index with the influenza transmission, ${ }^{1}$ no association of temperature and UV radiation with the COVID-19 epidemics has been reported, ${ }^{2}$ however, which may be denied by the present results of the association of lower temperature and higher sky cover with higher COVID-19 prevalence. In conclusion, lower temperature and higher wind speed/sky cover may be 
medRxiv preprint doi: https://doi.org/10.1101/2020.05.17.20104547; this version posted May 22, 2020. The copyright holder for this preprint (which was not certified by peer review) is the author/funder, who has granted medRxiv a license to display the preprint in perpetuity.

All rights reserved. No reuse allowed without permission.

associated with higher Covid-19 prevalence, which should be confirmed by further epidemiological researches adjusting for various risk and protective factors (in addition to meteorological conditions) of Covid-19.

\section{References}

1. Ianevski A, Zusinaite E, Shtaida N, et al. Low Temperature and Low UV Indexes Correlated with Peaks of Influenza Virus Activity in Northern Europe during 2010-2018. Viruses 2019;11:207.

2. Yao Y, Pan J, Liu Z, et al. No association of COVID-19 transmission with temperature or UV radiation in Chinese cities. Eur Respir J 2020;55:2000517.

3. Takagi H, Kuno T, Yokoyama Y, et al. Higher Air Temperature, Pressure, and Ultraviolet Are Associated with Less Covid-19 Incidence. medRxiv 2002 May 13. doi: 10.1101/2020.05.09.20096321.

\section{Figure legends}

Figure 1. Meta-regression graph depicting covid-19 prevalence (plotted as the logarithm transformed prevalence on the y-axis) as a function of the given factors (plotted as the meteorological data on the $\mathrm{x}$-axis). 
medRxiv preprint doi: https://doi.org/10.1101/2020.05.17.20104547; this version posted May 22, 2020. The copyright holder for this preprint (which was not certified by peer review) is the author/funder, who has granted medRxiv a license to display the preprint in perpetuity.

All rights reserved. No reuse allowed without permission.
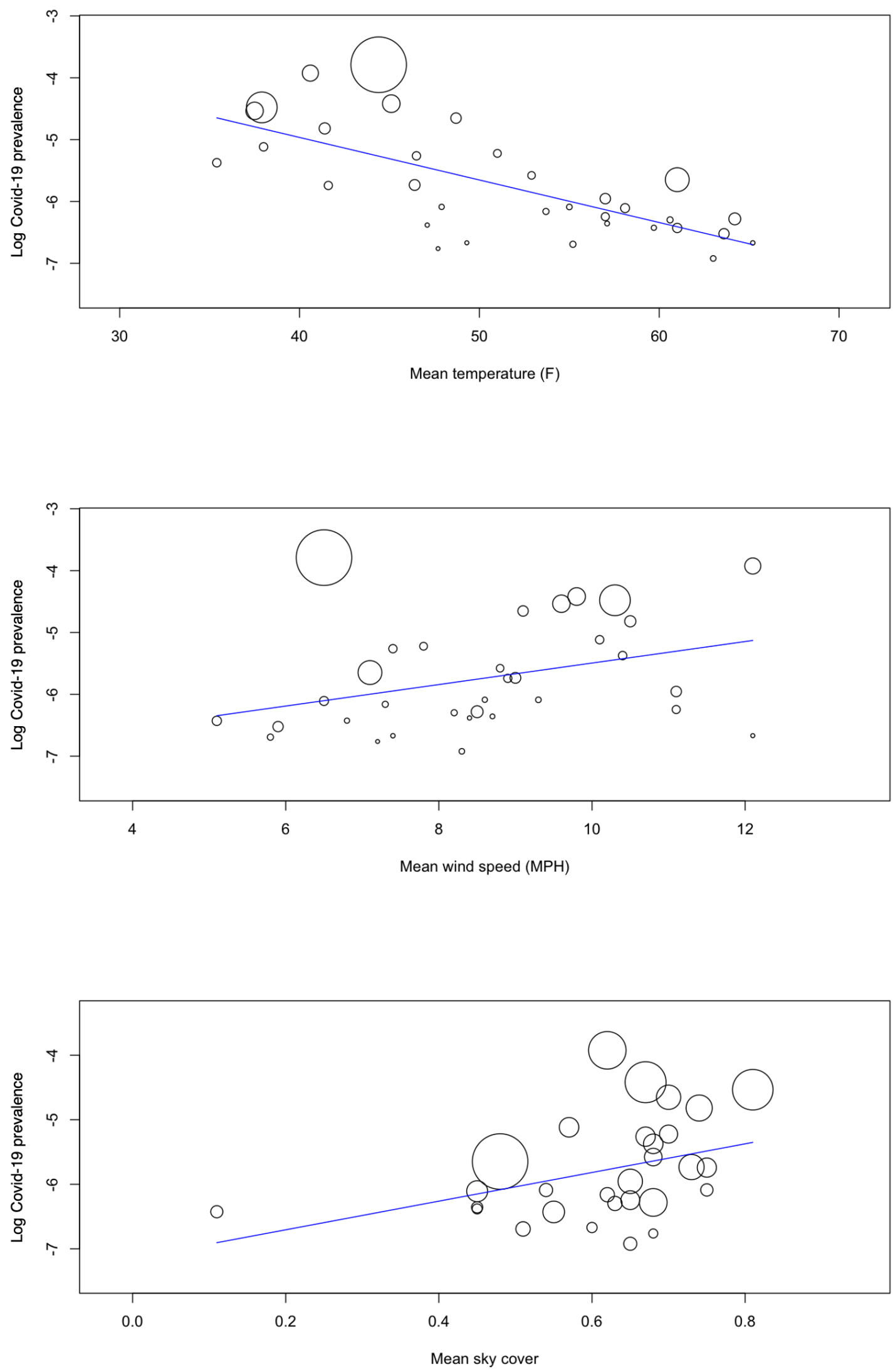
Table 1. Extracted data in each large U.S. city and country to which the city belongs.

\begin{tabular}{|c|c|c|c|c|c|c|c|c|c|c|}
\hline \multirow[t]{2}{*}{ City } & \multirow[t]{2}{*}{ State } & \multirow[t]{2}{*}{ County } & \multicolumn{3}{|c|}{ Covid-19 prevalence in the country } & \multicolumn{5}{|c|}{ Meteorological condition at the city } \\
\hline & & & Cases (N) & Population (N) & Prevalence & $\begin{array}{l}\text { Mean } \\
\text { temperature (F) }\end{array}$ & $\begin{array}{l}\text { Total precipitation } \\
\text { (inch) }\end{array}$ & $\begin{array}{l}\text { Mean wind } \\
\text { speed (MPH) }\end{array}$ & $\begin{array}{l}\text { Mean } \\
\text { sky cover }\end{array}$ & $\begin{array}{l}\text { Mean relative } \\
\text { humidity (\%) }\end{array}$ \\
\hline Albuquerque & New Mexico & Bernalillo & 1,149 & 679,121 & 0.00169 & 47.1 & 1.65 & 8.4 & 0.45 & 43 \\
\hline Austin & Texas & Travis & 2,345 & $1,273,954$ & 0.00184 & 60.6 & 12.06 & 8.2 & 0.63 & 72 \\
\hline Baltimore & Maryland & Baltimore & 4,290 & 827,370 & 0.00519 & 46.5 & 14.66 & 7.4 & 0.67 & 61 \\
\hline Boston & Massachusetts & Suffolk & 15,881 & 803,907 & 0.01975 & 40.6 & 12.62 & 12.1 & 0.62 & 58 \\
\hline Charlotte & North Carolina & Mecklenburg & 2,342 & $1,110,356$ & 0.00211 & 53.7 & 21.33 & 7.3 & 0.62 & 63 \\
\hline Chicago & Illinois & Cook & 58,457 & $5,150,233$ & 0.01135 & 37.9 & 10.86 & 10.3 & - & - \\
\hline Columbus & Ohio & Franklin & 4,227 & $1,316,756$ & 0.00321 & 41.6 & 19.31 & 8.9 & 0.75 & 67 \\
\hline Dallas & Texas & Dallas & 6,837 & $2,635,516$ & 0.00259 & 57.0 & 17.53 & 11.1 & 0.65 & 70 \\
\hline Denver & Colorado & Denver & 4,359 & 727,211 & 0.00599 & 38.0 & 2.82 & 10.1 & 0.57 & 57 \\
\hline Detroit & Michigan & Wayne & 18,770 & $1,749,343$ & 0.01073 & 37.5 & 11.35 & 9.6 & 0.81 & 73 \\
\hline D.C. & D.C. & - & 6,736 & 705,749 & 0.00954 & 48.7 & 14.61 & 9.1 & 0.70 & 63 \\
\hline El Paso & Texas & El Paso & 1,456 & 839,238 & 0.00173 & 57.1 & 3.07 & 8.7 & 0.45 & 40 \\
\hline Fort Worth & Texas & Tarrant & 4,076 & $2,102,515$ & 0.00194 & 57.0 & 17.53 & 11.1 & 0.65 & 70 \\
\hline Houston & Texas & Harris & 8,817 & $4,713,325$ & 0.00187 & 64.2 & 13.90 & 8.5 & 0.68 & 71 \\
\hline Indianapolis & Indiana & Marion & 7,793 & 964,582 & 0.00808 & 41.4 & 15.61 & 10.5 & 0.74 & 73 \\
\hline Jacksonville & Florida & Duval & 1,215 & 957,755 & 0.00127 & 65.2 & 6.36 & 7.4 & 0.60 & 68 \\
\hline Las Vegas & Nevada & Clark & 5,045 & $2,266,715$ & 0.00223 & 58.1 & 2.31 & 6.5 & 0.45 & 37 \\
\hline Los Angeles & California & Los Angeles & 35,392 & $10,039,107$ & 0.00353 & 61.0 & 7.17 & 7.1 & 0.48 & 62 \\
\hline Louisville & Kentucky & Jefferson & 1,741 & 766,757 & 0.00227 & 47.9 & 16.28 & 8.6 & 0.75 & 62 \\
\hline Memphis & Tennessee & Shelby & 3,542 & 937,166 & 0.00378 & 52.9 & 27.76 & 8.8 & 0.68 & 71 \\
\hline Milwaukee & Wisconsin & Milwaukee & 4,387 & 945,726 & 0.00464 & 35.4 & 10.52 & 10.4 & 0.68 & 66 \\
\hline Nashville & Tennessee & Davidson & 3,745 & 694,144 & 0.00540 & 51.0 & 23.11 & 7.8 & 0.70 & 64 \\
\hline New York City & New York & New York City & 188,545 & $8,336,817$ & 0.02262 & 44.4 & 12.74 & 6.5 & - & 57 \\
\hline Oklahoma City & Oklahoma & Oklahoma & 1,013 & 797,434 & 0.00127 & 49.3 & 10.86 & 12.1 & - & - \\
\hline Philadelphia & Pennsylvania & Philadelphia & 19,093 & $1,584,064$ & 0.01205 & 45.1 & 12.79 & 9.8 & 0.67 & 60 \\
\hline Phoenix & Arizona & Maricopa & 6,599 & $4,485,414$ & 0.00147 & 63.6 & 3.55 & 5.9 & - & 42 \\
\hline Portland & Oregon & Multnomah & 940 & 812,855 & 0.00116 & 47.7 & 12.35 & 7.2 & 0.68 & 71 \\
\hline San Antonio & Texas & Bexar & 1,976 & $2,003,554$ & 0.00099 & 63.0 & 7.35 & 8.3 & 0.65 & 66 \\
\hline San Diego & California & San Diego & 5,391 & $3,338,330$ & 0.00161 & 61.0 & 6.69 & 5.1 & 0.55 & 69 \\
\hline San Francisco & California & San Francisco & 1,999 & 881,549 & 0.00227 & 55.0 & 3.86 & 9.3 & 0.54 & 69 \\
\hline San José & California & Santa Clara & 2,391 & $1,927,852$ & 0.00124 & 55.2 & 4.06 & 5.8 & 0.51 & 65 \\
\hline Seattle & Washington & King & 7,290 & $2,252,782$ & 0.00324 & 46.4 & 18.15 & 9.0 & 0.73 & 73 \\
\hline Tucson & Arizona & Pima & 1,696 & $1,047,279$ & 0.00162 & 59.7 & 2.09 & 6.8 & 0.11 & 40 \\
\hline
\end{tabular}


Supplementary Table 2. Meta-regression summary.

\begin{tabular}{llllll}
\hline Covariate & \multicolumn{2}{l}{ Coefficient } & \multicolumn{2}{c}{ Standard error } & P value \\
\cline { 2 - 4 } & \multicolumn{3}{c}{ Lower bound } & Upper bound & \\
\hline Mean temperature (F) & -0.069 & -0.093 & -0.045 & 0.012 & $<0.001$ \\
Total precipitation (inch) & 0.038 & -0.004 & -0.081 & 0.022 & 0.075 \\
Mean wind speed (MPH) & 0.174 & 0.020 & 0.328 & 0.079 & 0.027 \\
Mean sky cover & 2.220 & 0.313 & 4.128 & 0.973 & 0.023 \\
Mean relative humidity (\%) & 0.007 & -0.020 & 0.035 & 0.014 & 0.613 \\
\hline
\end{tabular}

